\title{
PENGARUH CITRA MEREK DAN HARGA TERHADAP MINAT BELI HANDPHONE MEREK SAMSUNG PADA E-COMMERCE (STUDI KASUS PADA MAHASISWA FAKULTAS EKONOMI DAN BISNIS ANGKATAN 2017 UNIVERSITAS SINGAPERBANGSA KARAWANG)
}

\author{
Yustiani Rahayu, Salsabila Triadi, Shafira Ramadhanti Salsyabila, Danang Kusnanto \\ Universitas Singaperbangsa Karawang, Karawang \\ Jl. HS. Ronggo Waluyo, Puseurjaya, Kec. Telukjambe Timur, Karawang, Jawa Barat 41361 \\ rhytiani950@gmail.com
}

\begin{abstract}
Interest in Buying in companies in the field of electronics can be influenced by brand image and price where a good brand image can be used as a streght in attracting consumers and affordable product prices can increase the buying interest of consumers in the Samsung Company. From data analysis, There is partial influence between the brand image on the interest of buying with total effect 4,59\% and Price on the interest of buying with total effect $62,65 \%$. while simultaneous influence of brand image and price on buying interest with a determination coefficient of $67,2 \%$. This purpose of this Research was to find out, explain, analyze the Brand Image and Price on the Interest in Buying Samsung brand Handphone in Online on E-Commerce in College Students of the Faculty of Economics and Business Class of 2017 University of Singaperbangsa Karawang. The sample was carried out by the incidential sampling with a sample 186 respondents. Computer programs Microsoft Excel 2010 and SPSS version 16.
\end{abstract}

Keywords : Brand Image, Price, Buying Interest

\begin{abstract}
Abstrak
Minat beli pada perusahaan dibidang elekronik dapat dipengaruhi oleh citra merek dan harga dimana citra merek yang baik dapat dijadikan kekuatan dalam menarik konsumen dan harga produk yang terjangkau dapat meningkatkan minat beli calon konsumen Perusahaan Samsung. Dari hasil analisis data, Terdapat pengaruh parsial antara citra merek terhadap minat beli sebesar $4,59 \%$ dan harga terhadap minat beli sebesar $62,65 \%$. sedangkan pengaruh simultan dari citra merek dan harga terhadap minat beli dengan koefisien determinasi sebesar $67,2 \%$. Tujuan penelitian ini adalah mengetahui, menjelaskan dan menganalisis Citra Merek dan Harga terhadap Minat Beli Handphone Merek Samsung Secara Online Pada E-Commerce Pada Mahasiswa Fakultas Ekonomi dan Bisnis Angkatan 2017 Universitas Singaperbangsa Karawang. Sampel dilakukan dengan menggunakan metode Incidential Sampling dengan jumlah sampel 186 responden. Program komputer Microsoft Excel 2010 dan SPSS versi 16.
\end{abstract}

Kata kunci : Citra Merek, Harga, Minat Beli

\section{Pendahuluan}

Handphone atau smartphone telah menjadi alat komunikasi yang paling dicari oleh seluruh lapisan masyarakat, bukan hanya golongan masyarakat yang memiliki banyak aktivitas. Alat komunikasi (Handphone) yang bergitu populer ini telah menjadi tren baru dan tampaknya tidak dapat terpisahkan dari kebutuhan dan gaya hidup masyarakat Indonesia, terutama di kota-kota besar. Merekmerek dari jenis produk (handphone) ini tidak hanya bersaing dalam kecanggihan teknologi, tetapi juga pelayanan, harga, variasi bentuk, kejernihan suara, garansi pembelian dan kemudahan penggunaan. Berikut adalah survei dan analisis yang dilakukan oleh Internasional Data Coorporation (IDC) dan sosial gadget news yang terdapat pada Grafik 1.1 yang menunjukan penjualan handphone. 


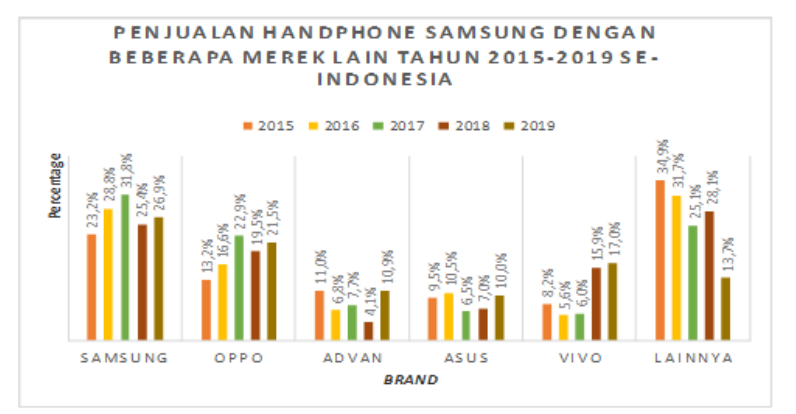

Gambar 1

Penjualan Handphone Samsung Dengan Beberapa Merek Lain Tahun 2015-2019 Se-Indonesia

Sumber: website Internasional Data Coorporation (IDC). Ulasan detik.com dan liputan6.com

\section{Teori Citra Merek}

Menurut Kotler (2008:32) menyatakan bahwa Citra merek sebagai seperangkat keyakinan, ide, dan kesan yang dimiliki oleh seseorang terhadap suatu merek, karena itu sikap dan tindakan konsumen terhadap suatu merek sangat ditentukan oleh citra merek tersebut. Citra merek merupakan syarat dari merek yang kuat. Menurut Buchari Alma (2008:121) syarat-syarat dari merek yang perlu diperhatikan adalah sebagai berikut:

a. Mudah diingat

Memilih merek sebaiknya mudah diingat, baik kata-katanya maupun gambarnya atau kombinasi sebab dengan demikian konsumen atau calon konsumen dapat mudah mengingatnya.

b. Menimbulkan kesan positif

Dalam memberikan merek diusahakan dapat memberikan kesan positif terhdap barang atau jasa yang akan dihasilkan.

c. Tempat untuk promosi

Selain kedua syarat diatas maka untuk merek tersebut sebaiknya dipilih yang bilamana dipakai untuk promosi yang baik. Selain menggunakan merek ang mudah diingat dan dapat menimbukan kesan positif, promosi dengan nama yang indah serta menarik juga memiliki peranan penting.

\section{Teori Harga}

Menurut Fandy Tjiptono menyatakan bahwa Harga merupakan satuan moneter atau ukuran lainnya (termasuk barang atau jasa lainnya) yang ditukarkan agar memperoleh hak kepemilikan atau penggunaan suatu barang atau jasa. Menurut Stanton (2004), beberapa faktor yang biasanya mempengaruhi keputusan penetapan harga, antara lain :

a. Permintaan produk

b. Target pangsa pasar

c. Reaksi pesaing

d. Penggunaan strategi penetapan harga: penetrasi ratai saringan

e. Produk, saluran distribusi dan promosi

f. Biaya memproduksi atau membeli produk

\section{Teori Minat Beli}

American Marketing Association menyatakan bahwa Minat beli adalah sebuah rencana untuk melakukan pembelian produk atau brand tertentu yang dibangun Iewat serangkaian proses pemilihan serta pengambilan keputusan. Minat beli konsumen pada suatu produk dapat dipengaruhi oleh beberapa unsur-unsur yang dipandang oleh konsumen dalam Fandy Tjiptono (2008:104) yaitu :
a. Struktur pembelian ( Kognitif )
b. Struktur Kepercayaan ( Afektif )
c. Struktur Tindakan ( Konatif )

\section{Metode Penelitian}

Menurut Sugiyono (2017:2) "Metode penelitian adalah cara ilmiah untuk mendapatkan data dengan tujuan dan kegunaan tertentu".

\section{a. Analisis Kualitatif}

Analisis kualitatif dimaksudkan untuk menganalisis data yang tidak ada hubungannya dengan angka-angka. Penyajiannya berupa keterangan, penjelasan, serta pembahasan secara tertentu.

b. Analisis Kuantitatif

Analisis kuantitatif digunakan untuk menganalisis data yang dinyatakan dalam bentuk angka-angka dimana data tersebut diperoleh dari jawaban kuesioner. Dalam penelitian ini analisis kuantitatif yang digunakan meliputi :
a) Uji Validitas.
b) Uji Reliabilitas.
c) Uji Normalitas
d) Koefisien korelasi. 
e) Regresi Sederhana.

f) Regresi Berganda.

g) Koefisien determinasi.

Adapun untuk pengujian hipotesis dilakukan pengujian :

a) Uji t, digunakan untuk mengetahui pengaruh variabel independen terhadap variabel dependen secara parsial. (Membandingkannya $t$ hitung dengan tabel t)

b) $U j i \mathrm{f}$, digunakan untuk mengetahui pengaruh variabel independen terhadap variabel dependen secara simultan.. (Membandingkannya f hitung dengan tabel f)

\section{Hasil dan Pembahasan Hasil}

Dari hasil penelitian, Pengaruh simultan citra merek dan harga terhadap minat beli adalah sebesar sebesar 0,672 berarti $67,2 \%$ dengan kriteria uji sig. $(0,000)<a(0,05)$ dan $f$ hitung $(187,584)>f$ tabel $(3,05)$ maka $\mathrm{HO}$ ditolak. Hal ini menunjukan bahwa variabel Citra Merek dan Harga memiliki konstribusi terhadap Minat Beli sebesar 67,2\% sedangkan sisanya $32,8 \%$ merupakan konstribusi variabel Iain yang tidak diteliti. Pengaruh parsial variabel citra merek terhadap minat beli nilainya adalah 0,0459 atau sebesar 4,59\% sedangkan Pengaruh parsial variabel harga terhadap minat beli yaitu sebesar 0,6265 atau sebesar 62,65\%. Hal ini menunjukan Harga lebih besar pengaruhnya kepada minat beli Handphone Merek Samsung dibandingkan dengan Citra Merek. Dengan demikian membuktikan bahwa variabel citra merek dan harga sama-sama memiliki konstribusi secara simultan terhadap minat beli.

\section{Pembahasan}

Dari hasil penelitian dapat disimpulkan bahwa variabel citra merek dan harga memilki pengaruh kepada minat beli, menurut Buchari Alma (2008:121) syarat-syarat dari merek yang perlu diperhatikan yaitu membuat produk yang mudah diingat kata-katanya ataupun gambarnya dengan demikian dapat mudah diingat , menimbulkan kesan positif akan produk yang dihasilkan dan mempunyai tempat untuk promosi yang baik agar menarik perhatian. Maka perusahaan Brand Image yang mudah diingat oleh konsumen dan memilki citra positif untuk terhadap produk dari merek tersebut. Dengan nilai signifikan $5 \%$ dan $t$ hitung $(2,774)>t$ tabel $(1,972)$. Dengan pengaruh parsial yaitu sebesar $4,59 \%$ sedangkan sisanya dipengaruhi oleh variabel lain selain variabel citra merek.

Menurut Stanton (2004), terdapat beberapa faktor penentu harga yaitu permintaan total terhadap produk, meningkatkan pangsa pasarnya bisa menetapkan harga dengan lebih agresif dengan harga yang lebih rendah dibandingkan perusahaan lain, Adanya persaingan baik yang sudah ada maupun yang masih potensial, menggunakan strategi penetapan harga saringan dan penetrasi, menetapkan harga sesuai dengan kriteria konsumen yang memilih produk dengan harga yang lebih murah dengan kualitas dan kriteria yang mereka perlukan dan dapat mempertimbangkan biayabiaya dalam produksi dan perubahan yang terjadi dalam kuantitas produksi agar menetapkan harga secara efektif. Dengan nilai signifikan $5 \%$ dan dan $t$ hitung $(17,278)>t$ tabel $(1,972)$ maka Pengaruh parsial variabel harga terhadap minat beli yaitu sebesar $62,65 \%$ sedangkan sisanya dipengaruhi oleh variabel lain selain variabel Harga.

Kemudian dalam penelitian ini juga dilakukan pengujian korelasi secara bersamasama antara variabel citra merek, harga dan minat beli yaitu variabel citra merek sebesar 0,320 sedangkan untuk variabel harga yaitu sebesar 0,371. Hal ini menunjukan bahwa Mahasiswa Fakultas Ekonomi Dan Bisnis Angkatan 2017 Universitas Singaperbangsa Karawang lebih mengutamakan faktor harga dibandingkan citra merek ketika berminat untuk membeli produk.

\section{Kesimpulan}

1. Variabel citra merek handphone samsung di fakultas ekonomi dan bisnis angkatan $2017 \quad$ Universitas Singaperbangsa Karawang dalam hasil penelitian bahwa sebagian besar responden menyatakan dalam kategori setuju.

2. Variabel harga handphone samsung di fakultas ekonomi dan bisnis angkatan 2017 Universitas Singaperbangsa Karawang berdasarkan hasil penelitian 
bahwa sebagian besar responden menyatakan dalam kategori setuju.

3. Variabel minat beli handphone samsung di fakultas ekonomi dan bisnis angkatan $2017 \quad$ Universitas Singaperbangsa Karawang berdasarkan hasil penelitian bahwa sebagian besar responden menyatakan dalam kategori setuju.

4. Berdasarkan pengujian hubungan antara citra merek dan harga diperoleh nilai koefisien korelasi yaitu sebesar 0,320 . artinya tingkat hubungan citra merek dan harga adalah rendah karena nilai variabel citra merek dan harga memiliki hubungan yang sedikit lemah dan variabel memiliki nilai yang naik turun yang berada pada rentang 0,200 - 0,399 namun positif dan searah. Sedangkan untuk Pengaruh parsial variabel citra merek terhadap minat beli nilainya adalah 0,0459 atau sebesar $4,59 \%$ sedangkan sisanya dipengaruhi oleh variabel lain.

5. Berdasarkan pengujian hubungan antara harga dan harga diperoleh nilai koefisien korelasi yaitu sebesar 0,371. artinya tingkat hubungan harga dan harga adalah rendah karena nilai variabel citra merek dan harga memiliki hubungan yang sedikit lemah dan variabel memiliki nilai yang naik turun yang berada pada rentang 0,200 0,399 namun positif dan searah. Sedangkan untuk Pengaruh parsial variabel harga terhadap minat beli nilainya adalah 0,6265 atau sebesar $62,65 \%$ sedangkan sisanya dipengaruhi oleh variabel lain.

6. Pengaruh simultan citra merek dan harga terhadap minat beli adalah sebesar 0,672 berarti $67,2 \%$ dan pengaruh variabel lain adalah sebesar 0,328 berarti $32,8 \%$ dengan hipotesis yang menunjukan kriteria uji signifikan adalah sebesar $5 \%$ dan $f$ hitung $(187,584)>f$ tabel $(3,05)$. Dengan demikian dapat disimpulkan bahwa citra merek dan harga berpengaruh secara simultan terhadap minat beli.

\section{Daftar Pustaka}

Apriansyah, Tatang. (2015). Pengaruh Kualitas Layanan dan Kepercayaan Terhadap Minat Beli Konsumen (Studi Kasus Pada Rest Area KM 57 Karawang). Universitas Singaperbangsa Karawang, Karawang.

Fredian, Melly Eka. (2016). Pengaruh Harga dan Kualitas Produk Terhadap Keputusan Pembelian Motor Honda Beat (Survei pada Mahasiswa Fakultas Ekonomi dan Bisnis Universitas Singaperbangsa Karawang). Universitas Singaperbangsa Karawang, Karawang.

Fristiana, Dessy Amelia. (2012). Pengaruh Citra Merek Dan Harga Terhadap Keputusan Pada Ramai Swalayan Peterongan Semarang (Studi Pada Konsumen Ramai Swalayan Peterongan Semarang).

Harmana, Abid. (2016). Pengaruh Kualitas Produk dan Harga Terhadap Minat Beli Konsumen di Rumah Makan Sindang Reret Karawang. Universitas Singaperbangsa Karawang, Karawang.

Isnayanti, Novi. (2016). Pengaruh Harga dan Kualitas Produk Terhadap Keputusan Pembelian Smartphone Samsung (Studi Kasus Pada Mahasiswa Fakultas Ekonomi dan Bisnis Universitas Singaperbangsa Karawang). Universitas Singaperbangsa Karawang, Karawang.

Juangsyah, Yoga Eka Prasetya. (2017). Pengaruh Gaya Hidup dan Citra Merek Terhadap Keputusan Pembelian Handphone Merek Iphone (Survei pada Mahasiswa Fakultas Ekonomi dan Bisnis Universitas Singaperbangsa Karawang). Universitas Singaperbangsa Karawang, Karawang.

Khoirunnisa. (2019). IDC: Top 5 Vendor Smartphone Global Q3-2019, Selular.ID. Diakses dari https://selular.id/2019/11/idc-top-5vendor-smartphone-global-q3-2019/ 
Kotler, Philip dan Kevin Lane Keller. (2008). Karawang).Universitas Singaperbangsa Manajemen Pemasaran-jilid satu. Karawang, Karawang. Jakarta: PT Indeks.

Kotler, Philip dan Gary Armstrong. (2008). Prinsip-prinsip Pemasaran-jilid dua. Jakarta: PT Indeks

Kotler, Philip dan Kevin Lane Keller. (2009). Manajemen Pemasaran. Edisi 13 Jilid 1. Jakarta : Erlangga

Miki Ambarwati, Sunarti, dan Mukhammad Kholid Mawardi. (2015). Pengaruh Citra Merek Terhadap Minat Beli (Survei Pada Mahasiswa Universitas Brawijaya Yang Menggunakan Pasta Gigi Pepsodent). Universitas Brawijaya, Malang.

Pariyah. (2015). Pengaruh Perilaku Konsumen Terhadap Minat Beli Air Mineral Isi Ulang Kemasan Galon (Survei Pada Perumahan De Griya, Gren Pertama, Putri Kosambi dan Tirai Mutiara Kecamatan Klari, Kabupaten Karawang). Universitas Singaperbangsa Karawang, Karawang.

Sangadji, Etta Mamang \& Sopiah. (2018). Perilaku Konsumen. Yogyakarta : Andi.

Sugiyono. (2017). Metode Penelitian (Kuantitatif Kualitatif dan R\&D). Bandung : Alfabeta

Suti, Intan. (2014). Pengaruh Kualitas Produk, Harga dan Promosi Terhadap Keputusan Pembelian Handphone Esia (Studi Kasus Pada Mahasiswa UIN Syarif Hidayatullah Jakarta). Universitas Islam Negeri Syarif Hidayatullah Jakarta, Jakarta.

Widodo, Guntur Bayu. (2016). Pengaruh Citra Merek dan Perilaku Konsumen Terhadap Keputusan Pembelian Handphone Sony Experia (Survei pada Mahasiswa Fakultas Ekonomi dan Bisnis Universitas Singaperbangsa 